\title{
AINSUSE PIKA JA LÜHIKESE SISSEÜTLEVA VALIKU OLENEMINE MORFOFONOLOOGILISTEST TUNNUSTEST - KORPUSANALÜÜS
}

\author{
ANN METSLANG
}

Annotatsioon. Kui varem on uurijad jõudnud tulemusele, et pika ja lühikese sisseütleva valik oleneb muu hulgas noomeni struktuurist, siis siinse artikli eesmärk on täpsustada, millised sõna morfofonoloogilised tunnused võivad sisseütleva vormi valikut mõjutada. Morfoloogiliselt ühestatud korpuse andmete analüüsimiseks kasutatakse statistilisi meetodeid: hii-ruut-testi ja standarditud Pearsoni jääke. Sisseütleva valiku tunnustena vaadeldakse astmevahelduslikkust, astmevahelduse liiki, astmevaheldusmalli, algvormi väldet, lõpuvahelduslikkust, Iõpuvaheldusmalli, algvormi lõpphäälikut ja omastavatüve silpide arvu. Nendest on hii-ruut-testi järgi sisseütleva valikul statistiliselt olulised kuus tunnust: astmevahelduslikkus, astmevahelduse liik, lõpuvahelduslikkus, lõpuvaheldusmall, algvormi lõpphäälik ja omastavatüve silpide arv. Lühikese sisseütleva kasutamine on standarditud Pearsoni jääkide põhjal tõenäolisem, kui sõna on astmevahelduslik (astmevahelduse liigilt laadivahelduslik), lõpuvahelduslik, nimetav lõpeb konsonandiga või kui omastavatüves on üle kolme silbi. Samuti, kui sõna on lõpuvaheldusmalli järgi seminar-, redel-, kringel-, siil-, sai-, lagi-, nali-, sõber- või õnnelik-tüüpi. Pika sisseütleva kasutamine on tõenäolisem, kui sõna on astmevahelduseta (või vältevahelduslik), lõpuvahelduseta (või lõpuvaheldusmallilt (V)s-lõpuline, suur-või küünal-tüüpi või (V)ne- ja ke-lõpuline, sh soolane-, uus-küüs- ja käsi-tüüpi), nimetav lõpeb vokaaliga või kui omastavatüves on kolm silpi. Siinse materjali põhjal kasutati aga kõigi tunnustega sõnade puhul rohkem aditiivivorme. Sisseütleva valikul ei ole statistiliselt olulised tunnused astmevaheldusmall ega algvormi välde.

Võtmesõnad: morfoloogia, morfofonoloogia, korpuslingvistika, keele varieerumine, illatiiv, aditiiv, eesti keel

1 Uurimistööd toetasid Euroopa Sotsiaalfond programmi DoRa kaudu, mida viib ellu Sihtasutus Archimedes, ja Alfred Kordelini Sihtasutus. Autor tänab retsensente metoodiliste ja sisuliste täienduste eest. 


\section{Põhimõisted. Varasemaid uurimusi}

Eesti keele sisseütlev kääne ehk illatiiv on oma ebaregulaarsuse tõttu pikka aega uurijatele huvi pakkunud. Selle käände ajaloost annavad kokkuvõtliku ülevaate näiteks Cornelius Hasselblatt (2000) ja Kati Kio (2006). Viimastes eesti keele grammatikates ja käsiraamatutes (EKG: 56-57; EKK: 245-247) käsitletakse sse-sisseütlevat kõigis sõnatüüpides võimaliku ja tavalisena. Lühikest sisseütlevat peetakse vaid võimalikuks paralleelvormiks, ehkki tegeliku keelekasutuse uuringud (Hasselblatt 2000; Kio 2006; Kaalep 2009) näitavad, et paljude sõnade puhul eelistatakse nimelt lühikest vormi. Just lühikese ja pika variandi varieerumine on sisseütleva käände kirjelduse üks teravamaid probleeme. Osa uurijaid käsitleb lühikest illatiivi ehk aditiivi ehk suunduvat käänet eraldi käändena (vt nt Rajandi 1963: 410; Viitso 1976: 152-153; Viks 1992). Tänapäevani pole aga aditiivi eesti keele käänete hulka arvatud, sest seda pole võimalik kõigist käändsõnadest moodustada. Siinses käsitluses kasutatakse selguse huvides lühikese sisseütleva vormide kohta terminit aditiiv. Ka materjali kogumiseks kasutatud morfoloogiliselt ühestatud korpuses nimetatakse lühikesi sisseütleva vorme Ülle Viksi (1992) süsteemi järgi aditiivivormideks.

Millest oleneb aga sisseütleva vormi valik? EKG kirjeldab lühikese sisseütleva kasutust, mis oleneb sõna fonoloogilis-derivatiivsest struktuurist (nt $i k$-lõpulistes sõnades on eelistatum lühike vorm) ning sõna leksikaalsest tähendusest (sh sellest, mis verbiga sõna koos esineb) ja (sellest tingitud) kasutussagedusest. Paljud sisseütleva vormid on adverbistunud või on tekkinud püsiühendid. Lühikese sisseütleva kasutus oleneb idiolektist ja see ei ole normikirjakeeles piiritletud. (EKG: 56-57)

Cornelius Hasselblatt käsitles 2000-t sisseütleva käände näidet ajakirjanduskeelest ja leidis, et eesti keele ainsuse sisseütlev on eelistatult lühike. Enamik pikkadest vormidest esines sõnades, mille puhul polnud lühike vorm teoreetiliselt võimalik (aastasse, raamatusse). Kui paralleelvariant oli võimalik, eelistati lühikest vormi. Erinevalt EKGs väidetust jõudis Hasselblatt tulemusele, et sisseütleva vormi valik ei olene verbist, millega vorm koos esineb. (Hasselblatt 2000: 801, 803)

Kati Kio andmed pärinevad õpilasküsitlustest ja lingvistikaolümpiaadi töödest. Kio jagas sõnad muuttüüpidesse ja leidis samuti, et paralleelvormistiku võimalikkuse korral eelistati lühikest vormi. Lühikest sisse- 
ütlevat eelistati pesa-ja sepp-tüübis, pikka sisseütlevat aga tööline-tüübis, sest selles tüübis satuks muidu kõrvuti kaks rõhulist silpi. Püsiühendites kasutatakse enamasti lühikest sisseütlevat, seega kivineb pigem lühike vorm. Kio väidab, et vormivalikut mõjutavad eelkõige noomeni struktuur ja kasutaja subjektiivne keeletaju. (Kio 2006: 113; 125-126)

Ka Heiki-Jaan Kaalep jõudis Tartu Ülikooli morfoloogiliselt märgendatud korpuse andmete põhjal tulemusele, et kui lühike sisseütlev on sõna häälikulise ja tuletusliku kuju tõttu võimalik, eelistatakse seda, v.a mõnekümne erandsõna puhul. ne- ja $s$-sõnade lühikese sisseütleva valik oleneb ka sõna pikkusest ja homonüümia vältimise vajadusest. (Kaalep 2009: 423)

Seega on uurijad jõudnud varem tulemusele, et sisseütleva vormi valik oleneb muu hulgas sõna struktuurist. Siinse artikli eesmärk on täpsustada, millised sõna struktuuri omadused võivad sisseütleva valikut mõjutada. Artiklis vaadeldakse kaheksat eesti keele noomenimuutmises olulist morfofonoloogilist tunnust, mille analüüsiga tahetakse anda panus sisseütleva valiku selgitamisse, kuigi tunnuste loetelu ei ole lõplik.

\section{Materjal ja meetod}

Materjal pärineb Tartu Ülikooli morfoloogiliselt ühestatud korpusest, kus on ilukirjanduse, ajakirjanduse, populaarteaduse ja seaduste tekstid ning transkribeeritud suuline kõne, kokku 613000 tekstisõna. Andmestikku võeti iga teine ainsuse illatiivi ja aditiivi vorm. Liitsõnade puhul arvestati ainult nende muutuvat põhiosa ning gi-/ $k i$-liitega vorme eraldi ei arvestatud. Niiviisi leiti kokku 2340 sisseütleva vormi, millest 1524 olid aditiivivormid ja 816 illatiivivormid. Ilma kordusteta oli materjali hulgas 464 aditiivivormi ja 360 illatiivivormi. Seega saab juba nende tulemuste põhjal kinnitada väidet, et eesti keele ainsuse sisseütlev on eelistatult lühike. Selle artikli eesmärk on siiski selgitada, mis põhjusel sellist sisseütleva vormi eelistatakse.

Et uurida illatiivi ja aditiivi varieerumist, võeti vaatluse alla ainult sellised vormid, mille puhul teoreetiliselt on võimalik rööpvormi moodustada. Siinjuures lähtuti 2013. aasta ÕSist. Nii võib näiteks vormil taskusse olla rööpvorm (aditiiv tasku), kuid vormil kõverasse mitte (ÕSi järgi ei saa moodustada aditiivi kõvera). Vaatluse alla ei võetud ka kaht juhtu, kus aditiivivorm oli moodustatud sõnadest, millest ÕSi järgi aditiivi 
moodustada ei saa: aditiivid Denveri ja keldri, mida normikirjakeeles ei aktsepteerita, st ÕSi järgi võiksid illatiivivormid olla ainult Denverisse ja keldrisse.

Omastava- ja osastavakujulist lõputa sisseütlevat kasutati vanemas kirjakeeles praegusest laialdasemalt. Osastavakujuline sisseütlev oli sselõpulise sisseütleva järel sageduselt järgmine sisseütleva kuju XIX sajandi teisel poolel (Sõnajalg 1956: 83). Virve Raagi (1998: 74) järgi lubati õigekeelsussõnaraamatutes lühikest sisseütlevat 14 sõnast (VÕS 1940), hiljem ainult neljast sõnast (VÕS 1953; ÕS 1960; ÕS 1976). Õpilastööde uuringutest on selgunud aga, et lõputa sisseütlevat kasutati ka vormides, kus see ei olnud õigekeelsusnormingute järgi võimalik (Nurm 1939: 11; Laugaste 1964: 398). Siinse materjali kahe juhu põhjal võib oletada, et lõputa sisseütlev pole tegelikust keelekasutusest endiselt veel nii taandunud, kui ÕSi normingud lubavad arvata.

Aditiivi- ja illatiivivormid valiti proportsionaalselt ehk sellest lähtudes, kui palju neid korpuses tegelikult oli, mitte võrdselt. Lõplikus materjalis on proportsionaalse valiku tulemusena 1522 aditiivivormi (kõik 1524 aditiivivormi, v.a Denveri ja keldri) ja 188 illatiivivormi (816st ainult need, millega oli aditiivi paralleelvorm ÕSi järgi võimalik) - kokku 1710 vormi. Nii moodustavad aditiivivormid kõigist vaadeldavatest vormidest $89 \%$ ja illatiivivormid $11 \%$ - aditiivivorme on umbes kaheksa korda rohkem kui illatiivivorme. Uuritav tunnus on sisseütleva vormi valik binaarne tunnus, mis võib olla aditiiv või illatiiv. Seletavad tunnused on astmevahelduslikkus, astmevahelduse liik, astmevaheldusmall, algvormi välde, lõpuvahelduslikkus, lõpuvaheldusmall, algvormi lõpphäälik ja omastavatüve silpide arv. Ühetunnuseline analüüs on hea indikaator, näitamaks, millised tunnused on olulised ka mitmetunnuselises analüüsis (Arppe 2008: 216-217). Tegu on nominaaltunnustega, st nende tasemete (nt väldete) vaheline kaugus pole arvuliselt mõõdetav.

Seletava ja uuritava tunnuse vahelise seose olulisuse määramiseks kasutati hii-ruut-testi, mis sobib nominaaltunnuste uurimiseks (vt nt Klavan 2012: 130-132, 148-173; Agresti 2013: 18). Iga seletava tunnuse juures on tabel seletava ja uuritava tunnuse seose kohta, kus esitatakse vaadeldavad sagedused ja sulgudes protsendid (mitu protsenti aditiividest või illatiividest mingile tunnuse tasemele vastas). Lisaks on toodud hii-ruut-testi tulemused: hii-ruut-statistik $X^{2}$, mis hindab, kas sisseütleva valiku ja vaadeldava tunnuse vahel on seos olemas, määramata sealjuures 
seose tugevust. Hii-ruut-statistiku järel on sulgudes vabadusastmete arv ja valimi suurus. Viimasena on toodud seose tugevust või statistilist olulisust kirjeldav väärtus $p$. Testi tulemus on statistiliselt oluline, kui $p<0,05$ ehk võimalus, et tulemus oli juhuslik, on väiksem kui 5\%. Iga tunnuse kohta on toodud ka standarditud Pearsoni jääkide tabel, mis esitab tunnustevahelise seose tugevuse ja suuna. Alan Agresti (2013: 81) järgi on standarditud Pearsoni jääkide puhul statistiliselt olulised tulemused alates absoluutväärtusest 2. Statistiline analüüs on tehtud statistikaprogrammiga R (R Development CoreTeam 2013). Samu meetodeid on kasutanud nt Antti Arppe (2008) leksikaalsete sünoüümide ja Jane Klavan (2012) grammatiliste sünonüümide uurimiseks.

\section{Tunnused}

Järgnevalt on toodud tunnused, mida statistilises analüüsis kasutatakse ja mis võiksid vormivalikut mõjutada. Kuna varem on leitud, et vormivalik oleneb muu hulgas sõna struktuurist, uuritakse sõna struktuuritunnuseid ehk morfofonoloogilisi tunnuseid. Seejuures ei määra ükski tunnus üksi sisseütleva vormi valikut. Artiklis tegeletakse probleemiga, kuidas morfoloogilist varieerumist uurida ja milliseid morfofonoloogilisi tunnuseid eesti keele noomenivormistiku varieerumise kirjeldamisel kindlalt arvesse võtta.

Astmevahelduslikkus. Iga analüüsitava sisseütlevavormi puhul määratakse, kas see kuulub astmevahelduslikku paradigmasse või mitte. Otsustamisel on aluseks 2013. a ÕS. Tegu on binaarse tunnusega, mille tasemed on 'ei' ja 'jah' olenevalt sellest, kas analüüsitav vorm kuulub astmevahelduslikku paradigmasse või mitte.

Astmevahelduse liik. Astmevahelduslikku paradigmasse kuuluvate vormide puhul täpsustatakse, kas tegu on välte- või laadivaheldusega. Vältevaheldust määratakse II ja III välte vaheldumise järgi sõna vormides, nt $h$ 'etk: hetke: $h$ 'etke; taevas : t'aeva : taevast. Laadivahelduse korral on sõna tugeva astme vormis teise silbi algul klusiil või $s$, mis nõrga astme vormis puudub, nt hammas : hamba : hammast; vesi : vee : vett. Kuna astmevahelduseta paradigmasse kuuluvad vormid jäävad kõrvale, on tunnus binaarne: tasemed on 'laadivaheldus' ja 'vältevaheldus'.

Astmevaheldusmall. Kui vorm kuulub astmevahelduslikku paradigmasse, täpsustatakse, kas astmevaheldus on tugevnev või nõrgenev. Seda määratakse omastavavormi järgi: kui omastavavorm on tugevas astmes, on 
tegu tugevneva astmevaheldusega (rooste : r 'ooste : roostet), kui nõrgas astmes, siis nõrgeneva astmevaheldusega (käsi : käe : kätt; $m$ äng: mängu : $m$ ‘ängu). Jällegi ei arvestata astmevahelduseta sõnu ning tunnus on binaarne: tasemed on astmevaheldusmalli järgi 'nõrgenev' ja 'tugevnev'.

Algvormi välde. Iga analüüsitava vormiga määratakse selle algvormi ehk ainsuse nimetava välde. Määramisel toetutakse 2013. a ÕSile. Tunnusel on kolm taset - 'I', 'II' ja 'III' - olenevalt sellest, kas algvorm on esma-, teise- või kolmandavälteline.

Lõpuvahelduslikkus. „Eesti keele käsiraamatu“ (EKK) järgi otsustatakse, kas analüüsitav vorm kuulub lõpuvahelduslikku paradigmasse või mitte. Konsonantlõpulised sõnad on alati lõpuvahelduslikud, kuna neile lisandub omastavas tüvevokaal. Ka ne- ja ke-lõpulised sõnad on alati lõpuvahelduslikud, nt inimene : inimese või tilluke : tillukese. Vokaallõpulistest sõnadest on lõpuvahelduslikud EKK järgi nimi-, tuli-, kole-, habe-, sai-, lagi-, käsi-, nali- ja pääse-tüüp. Tunnuse tasemed on 'ei' ja 'jah' olenevalt sellest, kas sõna on lõpuvahelduslik või mitte.

Lõpuvaheldusmall. Kui vorm kuulub lõpuvahelduslikku paradigmasse, määratakse EKK järgi lõpuvaheldusmall. EKKs on eristatud üheksa lõpuvaheldusmalli, kuid viis viimast neist on esimese kolme malli variandid ning neljandasse ei kuulu rööpse sisseütlevaga sõnu, seega kasutatakse siin artiklis vaid kolme EKK malli. Esimene mall on kõige tavalisem, lähtetüvi esineb ainult ainsuse nimetavas käändes ning kõigis teistes käänetes kasutatakse muutetüve. See mall iseloomustab EKK järgi seminar-, redel-, kringel-, siil-, sai-, lagi-, nali-, sõber- ja õnnelik-tüüpi sõnu, nt 'siil : siili: 'siili: 'siili/de: 'siile 'siili/sid. (EKK: 225-226)

Teise malli korral on lähtetüve levik kõige suurem; lähtetüve kasutatakse nii ainsuse osastavas kui ka mitmuse omastavas käändes. See mall iseloomustab eeskätt $s$-iga lõppevaid sõnu, kus $s$-i ees on vokaal, nt panus : panuse : panus/t : panus/te: panuse/id. Seda malli kasutavad ka suur-tüüpi sõnad, nt 'suur: suure: 'suur/t: suur/te: ‘suuri, ning küünal-tüüpi sõnad, nt küünal : küünla : küünal/t : küünal/de : küünla/id.

Kolmas mall on teise sarnane, kuid ainsuse osastavas ja mitmuse omastavas kasutatakse lähtetüve asemel lühenenud muutetüve. See mall iseloomustab eeskätt ke-ja ne-lõpulisi sõnu, kus -ne ees on vokaal. Nende sõnade lühenenud muutetüvi lõpeb järjendiga ,,vokaal $+s^{6}$. Selle malliga kirjeldatakse nt soolane-, uus-küüs- ja käsi-tüüpi sõnade vormistikku, nt 
'uns : uиe : 'un/t : un/te : 'unsi; käsi : 'käe : 'kä/tt : kä/te : käsi. (EKK: 231-233)

Lõpuvaheldusmallid on jaotatud kolmeks tunnuse tasemeks: '1', '2' ja '3' olenevalt malli numbrist EKKs.

Algvormi lõpphäälik. Määratakse ka nimetava ehk analüüsitava vormi algvormi lõpphäälik - kas tegu on konsonandi või vokaaliga. See on binaarne tunnus, millel on kaks taset: 'konsonant' ja 'vokaal'.

Omastavatüve silpide arv. Igal vormil määratakse tüvesilpide arv, mida loetakse omastavatüve silpide järgi. Andmestiku vormidel on üks kuni kuus tüvesilpi. Tunnus jagatakse neljaks tasemeks: olenevalt omastavatüve silpide arvust '1', '2' ja '3' ning '> 3', kui omastavatüves on üle kolme silbi.

Lisaks vaadeldi veel mõnd struktuuritunnust, mis jäid siinsest analüüsist välja. Näiteks määrati iga vormi puhul algvormi silbistruktuur: vokaalide ja konsonantide järjestus, nt algvorm maa on silbistruktuuriga CVV. Varieeruva sisseütlevaga sõnade puhul leiti 115 silbistruktuuri taset, mida on kasutatava statistilise testi jaoks selgelt liiga palju. Niisiis silbistruktuuri siinses analüüsis tunnusena ei arvestata. Ülle Viksi käsitluse (1992) järgi määrati ka kõigi sõnade muuttüüp, mis peaks ühtlasi olema kokkuvõtlikem viis sõna struktuuriomaduste kirjeldamiseks. Varieeruva sisseütlevaga sõnad jaotusid 25 muuttüüpi, mida aga on jällegi tunduvalt rohkem, kui oleks sobiv siin kasutatava meetodiga uurimiseks.

\section{Materjali analüüs}

\subsection{Astmevahelduslikkus}

Esimene vaadeldav morfofonoloogiline tunnus on astmevahelduslikkus. Uuritakse sõna paradigma astmevahelduslikkust, millel on kaks taset: 'ei' (sõna kuulub astmevahelduseta paradigmasse) või 'jah' (sõna kuulub astmevahelduslikku paradigmasse). Tabelist 1 nähtub, et andmestikus on rohkem astmevahelduslikke (1091 sõna 1710st) kui astmevahelduseta sõnu (619 sõna 1710st). Astmevahelduslike sõnade sisseütleva kasutus varieerub tunduvalt vähem: aditiivi kasutatakse märkimisväärselt rohkem (1067) kui illatiivi (24). 
Tabel 1. Astmevahelduslikkus ja ainsuse sisseütlev

\begin{tabular}{|l|c|c|c|}
\hline Astmevahelduslikkus & Aditiiv & Illatiiv & Kokku \\
\hline $\mathrm{Ei}$ & $455(30 \%)$ & $164(87 \%)$ & 619 \\
\hline Jah & $1067(70 \%)$ & $24(13 \%)$ & 1091 \\
\hline Kokku & $\mathbf{1 5 2 2 ( 1 0 0 \% )}$ & $\mathbf{1 8 8 ( 1 0 0 \% )}$ & $\mathbf{1 7 1 0}$ \\
\hline
\end{tabular}

Hii-ruut-testi tulemused näitavad, et tulemus on statistiliselt oluline: $X^{2}(1, N=1710)=238,21, p=<0,001$. Ka protsentide põhjal on näha seost aditiivi ja astmevahelduslike sõnade (70\%) ning illatiivi ja astmevahelduseta sõnade ( $87 \%$ ) vahel. Samuti on tabelis 2 toodud standarditud Pearsoni jääkide järgi tugev seos aditiivi ja astmevahelduslike sõnade ning illatiivi ja astmevahelduseta sõnade vahel. Kui vaadata esinemissagedust, on nii astmevahelduslike kui ka astmevahelduseta sõnade puhul eelistatud siiski aditiivivorme.

Tabel 2. Standarditud Pearsoni jäägid tabeli 1 kohta

\begin{tabular}{|l|c|c|}
\hline Astmevahelduslikkus & Aditiiv & Illatiiv \\
\hline Ei & $-15,43$ & 15,43 \\
\hline Jah & 15,43 & $-15,43$ \\
\hline
\end{tabular}

Tabelitest selgub, et astmevahelduslike sõnade puhul kasutatakse tõenäolisemalt aditiivi (aeda, aega, ahju) ja astmevahelduseta sõnade puhul illatiivi (alasse, algusesse, Ateenasse). Praeguses materjalis on aga mõlemal juhul aditiive rohkem ja illatiive vähem.

Teadaolevalt pole varem uuritud, kas sisseütleva valik võiks oleneda ainuüksi sõna astmevahelduslikkusest. Juba kolmest esimesest näitest selgub, et nende astmevahelduslike sõnade aditiiv langeb kokku osastavaga, mis kinnitab Heiki-Jaan Kaalepi (2009: 419-420) märgitud osastava ja aditiivi seost: lühike sisseütlev on sama mis ainsuse osastav, kui osastav on kolmandas vältes ja lõpeb täishäälikuga (aeda, aega, ahju). Homonüümsele osastavale lisaks on aditiiv ka nimetavavormiga samas astmes ja samas vältes, nii et ka taoline vormi läbipaistvus võib tingida aditiivi eelistamist. Kaalep (2012: 438) märgib ka, et ainsuse sisseütleva lõpp valitakse ainsuse osastava või nimetava järgi. Siinjuures on huvitav, et kuigi astmevahelduseta sõnade puhul on illatiivi kasutamine standarditud 
Pearsoni jääkide järgi tõenäolisem, on siiski eelistatud aditiivivorme. Järgnevates alapeatükkides uuritakse, kas sisseütleva valikut võiks mõjutada sõna astmevahelduse liik (välte- või laadivaheldus) või astmevaheldusmall (nõrgenev või tugevnev astmevaheldus).

\subsection{Astmevahelduse liik}

Kokku on materjali hulgas 1091 astmevahelduslikku sõna. Need on jaotatud kaheks tasemeks: 'laadivahelduslik' ja 'vältevahelduslik'. Tabelist 3 tuleb välja, et astmevahelduslikke illatiivivorme on aditiividest tunduvalt vähem ja ainult üks neist on laadivahelduslik - sõna jõud. Seega laadivahelduslike sõnade sisseütleva valik peaaegu ei varieerugi, mõnevõrra rohkem varieerub see vältevahelduslikel sõnadel, kus aditiivi kasutati 709 sõna puhul ja illatiivi 23 sõna puhul.

Tabel 3. Astmevahelduse liik ja ainsuse sisseütlev

\begin{tabular}{|l|c|c|c|}
\hline Astmevahelduse liik & Aditiiv & Illatiiv & Kokku \\
\hline Laadivaheldus & $358(34 \%)$ & $1(4 \%)$ & 359 \\
\hline Vältevaheldus & $709(66 \%)$ & $23(96 \%)$ & 732 \\
\hline Kokku & $1067(100 \%)$ & $24(100 \%)$ & 1091 \\
\hline
\end{tabular}

Hii-ruut-testi põhjal on tulemus statistiliselt oluline: $X^{2}(1, N=1091)=9,18$, $p=0,002$. Protsentide järgi on seos laadivahelduslike sõnade ja aditiivi (34\%) vahel suurem kui laadivahelduslike sõnade ja illatiivi (4\%) vahel, samuti on suurem seos vältevahelduslike sõnade ja illatiivi (96\%) kui vältevahelduslike sõnade ja aditiivi (66\%) vahel. Ka standarditud Pearsoni jäägid (tabel 4) näitavad, et laadivahelduslike sõnade puhul kasutatakse veidi tõenäolisem aditiivi ( $a e d a, a e g a, e m b a-k u m b a$ ) ja vältevahelduslike puhul illatiivi (asjasse, hetkesse, kõigesse). Mõlemal juhul on materjalis siiski aditiivivorme tunduvalt rohkem kui illatiivivorme.

Tabel 4. Standarditud Pearsoni jäägid tabeli 3 kohta

\begin{tabular}{|l|c|c|}
\hline Astmevahelduse liik & Aditiiv & Illatiiv \\
\hline Laadivaheldus & 3,03 & $-3,03$ \\
\hline Vältevaheldus & $-3,03$ & 3,03 \\
\hline
\end{tabular}


Aditiivi ja laadivahelduslikkuse seos kinnitab Kaalepi (2009: 419-420) väidet, mille järgi lühike sisseütlev on sama mis ainsuse osastav, kui osastav on kolmandas vältes ja lõpeb täishäälikuga, nagu ka siin toodud laadivahelduslike vormide näited. Siinse materjali põhjal ei kehti aga nõrgem seos, mille järgi vältevahelduslike sõnade puhul on tõenäolisem kasutada illatiivivorme, sest mõlemal juhul on eelistatud aditiivivorme.

\subsection{Astmevaheldusmall}

Peale astmevahelduse liigi vaadati ka astmevaheldusmalli. 1091 sõna jagati astmevahelduse suuna järgi kaheks tasemeks: 'nõrgenev' ja 'tugevnev'. Tugevneva astmevaheldusega sõnu on andmestikus ainult neli: lõuna, rooste, taevas ja toime. Nõrgeneva astmevaheldusega sõnu ongi eesti keeles tunduvalt rohkem kui tugevneva astmevaheldusega sõnu (vt nt Viks 1992: 43-46). Nii saab iga sõna puhul anda konkreetsed eelistused. Sõnade lõuna ja taevas puhul eelistatakse illatiivi: lõunasse (8 korda) ja taevasse (4 korda); aditiivis on aga rooste (2 korda) ja toime (40 korda). Toime on korpuses liigitatud substantiiviks, kuigi mõne käsitluse järgi võiks tegu olla muutumatu sõnaga, (afiksaal)adverbiga, näiteks ühendis toime panema, mis esineb 25 korda. Kuna ühend esineb nii sagedasti, võib seda pidada püsivalt kokkukuuluvaks ehk püsiühendiks. Aditiivi kasutamine püsiühendis on ootuspärane, ka Kati Kio (2006: 126) töös leidunud püsiühendites on kasutatud enamasti lühikest sisseütlevat, st lühike sisseütlev oli kivinev ja oma põhitähendust kaotav vorm. Andmete põhjal on koostatud tabel 5, kust selgub, et rohkem varieerub tugevneva astmevaheldusega sõnade sisseütleva valik.

Tabel 5. Astmevaheldusmall ja ainsuse sisseütlev

\begin{tabular}{|l|c|c|c|}
\hline Astmevaheldusmall & Aditiiv & Illatiiv & Kokku \\
\hline Nõrgenev & $1025(96 \%)$ & $12(50 \%)$ & 1037 \\
\hline Tugevnev & $42(4 \%)$ & $12(50 \%)$ & 54 \\
\hline Kokku & $1067(100 \%)$ & $24(100 \%)$ & 1091 \\
\hline
\end{tabular}

Protsentide järgi on seos aditiivi ja nõrgeneva astmevahelduse vahel 96\%. See on ka ainus info, mis nõrgeneva ja tugevneva astmevahelduse kohta esitada saab. 
Niisiis on tõenäolisem, et nõrgeneva astmevaheldusega sõnade puhul kasutatakse aditiivi. Kuna illatiivis on nõrgeneva ja tugevneva astmevaheldusega vorme võrdselt, ei saa illatiivi kasutamise tõenäosuse kohta midagi väita - hii-ruut-test ja standarditud Pearsoni jäägid ei anna programmiga R usaldusväärseid tulemusi. Siinsed andmed kinnitavad Virve Raagi (1998: 73) väidet, et lõputa sisseütlev (aditiiv) on väga sage nõrgeneva astmevaheldusega sõnades. Tugevneva astmevaheldusega sõnade hulgas leidub omastavaga homonüümseid aditiivivorme rooste ja toime. Seejuures aga ülejäänud kaks sõna andmestiku neljast tugevneva astmevaheldusega sõnast ei esine kordagi aditiivis: pole näiteid aditiivivormide lõuna ja taeva kohta.

\subsection{Algvormi välde}

Välde on tunnus, mis jaguneb eesti keeles kolmeks. Kui algvorm on esimeses vältes, on tase 'I', teises vältes - 'II' ja kolmandas vältes - 'III'. Saadud sagedused on antud tabelis 6 . Enim varieeruvad sisseütleva vormi valikul kolmandavältelised sõnad, vähem teisevältelised ja kõige vähem esmavältelised.

Algvormi väldet on käsitlenud ka Kaalep, mainides, et lühikese sisseütleva se-lõpuline vorm on normikohaselt võimalik sõnadest, mille ainsuse omastava tüvi on -(V)se, tüvi on pikem kui kolm silpi või on kolmandas vältes ja kolmesilbiline. Kaalep toob välja tendentsi, et selliste pikemate sõnade sisseütlev on se-lõpuline (aditiiv). (Kaalep 2009: 422)

Tabel 6. Algvormi välde ja sisseütleva vorm

\begin{tabular}{|l|c|c|c|}
\hline Algvormi välde & Aditiiv & Illatiiv & Kokku \\
\hline I & $345(23 \%)$ & $53(28 \%)$ & 398 \\
\hline II & $201(13 \%)$ & $25(13 \%)$ & 226 \\
\hline III & $976(64 \%)$ & $110(59 \%)$ & 1086 \\
\hline Kokku & $1522(100 \%)$ & $188(100 \%)$ & 1710 \\
\hline
\end{tabular}

Hii-ruut-testi järgi ei ole tulemus statistiliselt oluline: $X^{2}(2, N=1710)=$ $3,03, p=0,22$. Protsentide põhjal on esmavältelised sõnad pigem illatiivis (28\%) ja kolmandavältelised pigem aditiivis (64\%). Teisevälteliste sõnade vormieelistuste kohta aga protsentide järgi järeldusi teha ei saa - aditiive 
on küll rohkem (201) kui illatiive (25), kuid tervikust moodustavad mõlemad 13\%. Nii võiks arvata, et esmavälteliste sõnade puhul kasutatakse tõenäolisemalt illatiivi ja kolmandavälteliste puhul aditiivi, kuid standarditud Pearsoni jäägid seda ei kinnita, sest ei andnud ühegi seose puhul tulemust absoluutarvuga vähemalt 2. Seetõttu standarditud Pearsoni jääke siinkohal ei esitata.

\subsection{Lõpuvahelduslikkus}

Sel tunnusel on kaks taset: 'jah', kui vorm kuulub lõpuvahelduslikku paradigmasse, ja 'ei', kui vorm kuulub lõpuvahelduseta paradigmasse.

Tulemused on esitatud tabelis 7. Sellest selgub, et varieeruvad pigem lõpuvahelduseta, mitte lõpuvahelduslikud sõnad.

Lõpuvaheldusele alluvad väga erinevad sõnad. Silmas on peetud näiteks nii ne-lõpuliste sõnade lõpuvaheldust -ne : -se kui ka kõiki konsonantlõpulisi sõnu, millele lisandub omastavas tüvevokaal. Teadaolevalt pole varem uuritud, kas mistahes lõpuvaheldus võiks sisseütleva vormi valikut mõjutada. Lõpuvahelduslikke omastavas (V)se-ga lõppevaid sõnu, mille tüvi on pikem kui kolm silpi (harjutus, oluline) või on kolmandas vältes ja kolmesilbiline (kurbus, peamine), on käsitlenud Kaalep (2009: 422), kes sai tulemuseks, et nende puhul on eelistatud aditiivi.

Tabel 7. Lõpuvahelduslikkus ja ainsuse sisseütlev

\begin{tabular}{|l|c|c|c|}
\hline Lõpuvahelduslikkus & Aditiiv & Illatiiv & Kokku \\
\hline $\mathrm{Ei}$ & $335(22 \%)$ & $132(70 \%)$ & 467 \\
\hline Jah & $1187(78 \%)$ & $56(30 \%)$ & 1243 \\
\hline Kokku & $\mathbf{1 5 2 2 ( \mathbf { 1 0 0 } \% )}$ & $\mathbf{1 8 8 ( 1 0 0 \% )}$ & $\mathbf{1 7 1 0}$ \\
\hline
\end{tabular}

Tulemus on statistiliselt oluline: $X^{2}(1, N=1710)=195,85, p=<0,001$. Tabeli 7 protsentide järgi selgub, et on olemas seos lõpuvaheldusega sõnade ja aditiivi (78\%) ning lõpuvahelduseta sõnade ja illatiivi (70\%) vahel. Ka standarditud Pearsoni jäägid (tabel 8) näitavad, et lõpuvaheldusega sõnade sisseütlevana kasutatakse tõenäoliselt aditiivi (aeda, aega, ahju) ja lõpuvahelduseta sõnade sisseütlevana tõenäolisemalt illatiivi (alasse, Ateenasse, avasse). Siinses materjalis on aga aditiivi eelistatud mõlemal juhul, nii lõpuvahelduslike kui ka lõpuvahelduseta sõnade puhul. 
Tabel 8. Standarditud Pearsoni jäägid tabeli 7 kohta

\begin{tabular}{|l|c|c|}
\hline Lõpuvahelduslikkus & Aditiiv & Illatiiv \\
\hline $\mathrm{Ei}$ & $-13,99$ & 13,99 \\
\hline Jah & 13,99 & $-13,99$ \\
\hline
\end{tabular}

Nii standarditud Pearsoni jääkide kui ka siinse materjali esinemissageduse järgi saab väita, et lõpuvaheldusega sõnades eelistatakse aditiivi. Paljud neist aditiividest on osastavaga homonüümsed - see on seos, mis on ilmnenud ka eelkäsitletud tunnuste puhul.

Lõpuvahelduseta on aga näiteks pesa-tüüp, mis Kio (2006: 125-126) tulemuste järgi on eelistatult aditiivis. Siinsele materjalile tuginedes on standarditud Pearsoni jääkide järgi lõpuvahelduseta sõnade puhul tõenäolisem illatiivi kasutamine, kuid esinemissageduse põhjal leidus siiski rohkem aditiivivorme. Lõpuvahelduseta sõnade aditiivivorme, nagu alla, Ateena, $a v v a$, tegelikus keelekasutuses arvatavasti ei kasutata, vaid eelistatakse läbipaistvamaid illatiivivorme alasse, Ateenasse, avasse. Edaspidi tuleks aga täpsemalt uurida, millistel tingimustel eelistatakse näiteks pesa-tüübis aditiivi ja millistel illatiivi.

\subsection{Lõpuvaheldusmall}

Lõpuvahelduslikke sõnu oli materjalis kokku 1243 ja need on jaotatud kolme malli vahel. Esimesse malli (tase '1') kuuluvad seminar-, redel-, kringel-, siil-, sai-, lagi-, nali-, sõber- ja õnnelik-tüüpi sõnad. Teise malli (tase '2') kuuluvad peamiselt (V)s-lõpulised sõnad, aga ka suur- ning küünal-tüüpi sõnad. Kolmas mall (tase '3') iseloomustab eeskätt (V)neja ke-lõpulisi sõnu. Selle malliga kirjeldatakse nt soolane-, uus-küüs- ja $k a ̈ s i$-tüüpi sõnade vormistikku. Täpsemalt on malle kirjeldatud peatükis 3 .

Tabelist 9 selgub, et enim varieeruvad kolmanda lõpuvaheldusmalliga sõnad, seejärel teise lõpuvaheldusmalliga ja kõige vähem esimese malliga sõnad. 
Tabel 9. Lõpuvaheldusmall ja ainsuse sisseütlev

\begin{tabular}{|l|c|c|c|}
\hline Lõpuvaheldusmall & Aditiiv & Illatiiv & Kokku \\
\hline 1 & $835(70 \%)$ & $19(34 \%)$ & 854 \\
\hline 2 & $214(18 \%)$ & $19(34 \%)$ & 233 \\
\hline 3 & $138(12 \%)$ & $18(32 \%)$ & 156 \\
\hline Kokku & $1187(100 \%)$ & $56(100 \%)$ & 1243 \\
\hline
\end{tabular}

Tulemus on statistiliselt oluline: $X^{2}(2, N=1243)=35,47, p=<0,001$. Protsentide põhjal on esimesse lõpuvaheldusmalli kuuluvad sõnad pigem aditiivis, teise malli sõnad pigem illatiivis ja kolmanda malli sõnad jällegi pigem illatiivis. Standarditud Pearsoni jäägid on toodud tabelis 10, mille järgi on seos aditiivi ja esimese lõpuvaheldusmalli vahel ning illatiivi ja teise ning kolmanda lõpuvaheldusmalli vahel.

Tabel 10. Standarditud Pearsoni jäägid tabeli 9 kohta

\begin{tabular}{|l|c|c|}
\hline Lõpuvaheldusmall & Aditiiv & Illatiiv \\
\hline 1 & 5,74 & $-5,74$ \\
\hline 2 & $-2,98$ & 2,98 \\
\hline 3 & $-4,53$ & 4,53 \\
\hline
\end{tabular}

Tabelist 10 selgub, et esimesse malli kuuluvate sõnade puhul kasutatakse veidi tõenäolisemalt aditiivi (aeda, aega, ahju), teise malli sõnade puhul tõenäolisemalt illatiivi (algusesse, keskusesse, kõrgusesse) ja kolmanda malli sõnade puhul taas illatiivi (endisesse, kinnisesse, saamisesse). Niisiis kehtib taas Kaalepi (2009: 419-420) väide, et lühike sisseütlev on sama mis ainsuse osastav, kui osastav on kolmandas vältes ja lõpeb täishäälikuga (nagu aeda, aega, ahju). Teise ja kolmandasse malli kuuluvate (V)s- ja (V)ne-lõpuliste sõnade puhul tundub, et kolmesilbilise tüvega sõnades võidakse pikka vormi kasutada loomulikuma rõhustruktuuri tõttu. Seda kinnitab ka Kio (2006: 125-126), kes märgib, et tööline-tüübis eelistatakse illatiivi, sest aditiivi puhul satuks kõrvuti kaks rõhulist silpi. Siiski on kasutatud praeguses materjalis ka nende sõnade puhul rohkem aditiivi, kuigi tõenäolisem oleks illatiivi kasutamine. 


\subsection{Algvormi lõpphäälik}

Sel tunnusel on kaks taset: 'C', kui algvorm lõpeb konsonandiga, ja 'V', kui algvorm lõpeb vokaaliga.

Kaalep (2009) seob sisseütleva moodustamise osastava vormiga, käsitledes struktuuritunnuste hulgas ka lõpphäälikut. Kaalep märgib (2009: 420), et nii ühesilbilistest (trotuaar, president) kui ka kolmesilbilistest (akvaarium, misjonär, orjatar) kaashäälikuga lõppevatest ja ik-liitega sõnadest (võsastik, õnnelik) on võimalik moodustada (osastava eeskujul) lühikest sisseütlevat, ning korpuse andmetel nendes kaashäälikuga lõppevates tüüpides ka eelistatakse aditiivi.

Kaalep vaatleb eraldi ka sisseütleva vorme, mille ainsuse nimetav Iõpeb täishäälikuga. Ta jõuab tulemusele, et lühikest sisseütlevat moodustatakse kahesilbilistest täishäälikuga lõppevatest või elu-lõpulistest sõnadest (tüübid saba, sõda, nimi, jõgi, padi), aga ka ühesilbilistest sõnadest (lai, sai). Täishäälikuga lõppevate tüüpide puhul on aga aditiivi kasutus piiratud ja seega ebaproduktiivne. (Kaalep 2009: 420-421)

Siinsed tulemused on toodud tabelis 11 , kust nähtub, et rohkem varieerub vokaallõpuliste sõnade sisseütleva valik.

Tabel 11. Algvormi lõpphäälik ja ainsuse sisseütlev

\begin{tabular}{|l|c|c|c|}
\hline Algvormi lõpphäälik & Aditiiv & Illatiiv & Kokku \\
\hline C & $975(64 \%)$ & $32(17 \%)$ & 1007 \\
\hline V & $547(36 \%)$ & $156(83 \%)$ & 703 \\
\hline Kokku & $1522(100 \%)$ & $188(100 \%)$ & 1710 \\
\hline
\end{tabular}

Neid tulemusi saab pidada statistiliselt oluliseks: $X^{2}(1, N=1710)=$ $152,93, p=<0,001$. Juba protsentidest nähtub, et on olemas seos aditiivi ja konsonantlõpu vahel (64\%) ning illatiivi ja vokaallõpu (83\%) vahel. Ka standarditud Pearsoni jääkide järgi (tabel 12) saab täheldada seost aditiivi ja konsonantlõpuliste sõnade (aeda, aega, akti) ning illatiivi ja vokaallõpuliste sõnade (alasse, asjasse, Ateenasse) vahel. Esinemissageduse põhjal on aga mõlemal juhul eelistatud aditiivi. 
Tabel 12. Standarditud Pearsoni jäägid tabeli 11 kohta

\begin{tabular}{|l|c|c|}
\hline Algvormi lõpphäälik & Aditiiv & Illatiiv \\
\hline C & 12,37 & $-12,37$ \\
\hline V & $-12,37$ & 12,37 \\
\hline
\end{tabular}

Siinsed tulemused kinnitavad Kaalepi väidet, et konsonantlõpuliste sõnade sisseütlev on valdavalt lühike (aditiiv). Standarditud Pearsoni jäägid kinnitavad väidet, mille järgi vokaallõpuliste sõnade aditiivi kasutamine võiks olla piiratud ja seega on tõenäolisem illatiiv.

Siinjuures on huvitav, et tavaliselt koos käsitletavad $s$ - ja ne-lõpulised sõnad paiknevad selle jaotuse järgi eri tasemetel. $s$-lõpuliste sõnade puhul on siinse jaotuse järgi tõenäolisem aditiivi kasutamine, eeldatavasti mõjutavad haploloogia (kahest kõrvuti asetsevast sarnasest silbist või häälikust ühe väljajätmine, nt alluvu/se/sse - alluvu/sse) ja häälduse mugavus. $n e$-lõpuliste sõnade puhul võiks aga tõenäolisem olla illatiivi kasutamine. Arvatavasti on ne-sõnade hulgas palju kolmesilbilise tüvega sõnu, mille puhul langeks lühikeses sisseütlevas kõrvuti kaks rõhulist silpi, mistõttu võidakse eelistada pikki vorme (Kio 2006: 125-126).

\subsection{Omastavatüve silpide arv}

Omastavatüve silpide arvul on neli taset: '1', kui tüves on üks silp, '2', kui kaks silpi, '3', kui kolm silpi, ja '> 3', kui tüves on 4-6 ehk üle kolme silbi. Tabelist 13 selgub, et enim varieerub kolmesilbilise tüvega sõnade sisseütleva valik. Kõige vähem varieerub aga pikema kui kolmesilbilise tüvega sõnade sisseütlev, mis on peaaegu kõigil juhtudel aditiiv.

Tabel 13. Omastavatüve silpide arv ja ainsuse sisseütlev

\begin{tabular}{|l|c|c|c|}
\hline Omastavatüve silpide arv & Aditiiv & Illatiiv & Kokku \\
\hline 1 & $100(7 \%)$ & $7(4 \%)$ & 107 \\
\hline 2 & $1058(70 \%)$ & $141(75 \%)$ & 1199 \\
\hline 3 & $94(6 \%)$ & $38(20 \%)$ & 132 \\
\hline$>3$ & $270(18 \%)$ & $2(1 \%)$ & 272 \\
\hline Kokku & $1522(100 \%)$ & $188(100 \%)$ & 1710 \\
\hline
\end{tabular}


See tulemus on statistiliselt oluline: $X^{2}(3, N=1710)=74,85, p=<0,001$. Protsentide järgi selgub, et ühesilbilise tüve puhul kasutatakse rohkem aditiivi (7\%), kahesilbilise tüve puhul rohkem illatiivi (75\%), kolmesilbilise tüve puhul rohkem illatiivi (20\%) ja üle kolme tüvesilbi korral aditiivi (18\%). Esinemiskordade järgi on aga kõigil juhtudel eelistatud aditiivi. Standarditud Pearsoni jäägid on toodud tabelis 14. Selle põhjal on seos kolmesilbilise tüvega sõnade ja illatiivi (algusesse, Ateenasse, endisesse) ning pikemate kui kolmesilbilise tüvega sõnade ja aditiivi (ajastamisse, akvatooriumi, alevikku) vahel.

Tabel 14. Standarditud Pearsoni jäägid tabeli 13 kohta

\begin{tabular}{|l|c|c|}
\hline Omastavatüve silpide arv & Aditiiv & Illatiiv \\
\hline 1 & 1,52 & $-1,52$ \\
\hline 2 & $-1,55$ & 1,55 \\
\hline 3 & $-6,8$ & 6,8 \\
\hline$>3$ & 5,9 & $-5,9$ \\
\hline
\end{tabular}

Tabeli 14 järgi ei ole ühe- ja kahesilbilistel sõnadel tugevat seost aditiivi ega illatiivi valikuga. Kolmesilbilise tüvega sõnad on tõenäolisemalt illatiivis, pikema kui kolmesilbilise tüve korral on tõenäolisem aditiiv. Siinses materjalis oli aga mõlemal juhul rohkem aditiivivorme. Tõenäoliselt võidakse kolmesilbilise tüvega sõnades kasutada illatiivi, kui $s$ - ja ne-lõpuliste sõnades satuks kõrvuti kaks rõhulist silpi. Pikema kui kolmesilbilise tüvega sõnad on aga pigem aditiivis haploloogia ja hääldusmugavuse tõttu.

\section{Kokkuvõte}

Artiklis vaadeldi Tartu Ülikooli morfoloogiliselt ühestatud korpuse 1710 sisseütlevavormi, millega on illatiivi ja aditiivi varieerumine teoreetiliselt võimalik. Varieerumise võimalikkuse üle otsustamisel toetuti 2013. a ÕSile. Kuna varem on leitud, et sisseütleva varieerumine oleneb morfofonoloogilistest tunnustest, uuriti hii-ruut-testi ja standarditud Pearsoni jääkidega kaheksat tunnust: astmevahelduslikkust, astmevahelduse liiki, astmevaheldusmalli, algvormi väldet, lõpuvahelduslikkust, lõpuvaheldusmalli, algvormi lõpphäälikut ja omastavatüve silpide arvu. Kuna varem on leitud, et sisseütleva vormi valikut mõjutavad muu hulgas 
morfofonoloogilised tunnused, oli siinse artikli eesmärk välja selgitada, millised neist tunnustest võivad sisseütleva vormi valikule mõju avaldada. Seetõttu uuriti, millised neist tunnustest on hii-ruut-testi järgi statistiliselt olulised ning mis tunnuste korral on standarditud Pearsoni jääkide järgi tõenäolisem aditiivi kasutamine ja mis tunnuste korral illatiivi kasutamine. Nii saab statistiliselt olulised tunnused kaasata mitmetunnuselisse analüüsi, kus uurida lisaks ka morfosüntaktilisi ja semantilisi tunnuseid. Uurimusest selgus, et vaadeldud tunnustest on hii-ruut-testi järgi sisseütleva valikul statistiliselt olulised kuus: astmevahelduslikkus (ka astmevahelduse liik), lõpuvaheldus (ka lõpuvaheldusmall), algvormi lõpphäälik ja omastavatüve silpide arv. Standarditud Pearsoni jääkide järgi on aditiivi kasutamine tõenäolisem, kui sõna on astmevahelduslik, astmevahelduse liigilt laadivahelduslik, lõpuvahelduslik, nimetav lõpeb konsonandiga või omastavatüves on üle kolme silbi. Lõpuvaheldusmallide järgi on aditiivis tõenäolisemalt seminar-, redel-, kringel-, siil-, sai-, lagi-, nali-, sõber- ja õnnelik-tüüpi sõnad. Standarditud Pearsoni jääkide põhjal on illatiivi kasutamine tõenäolisem, kui sõna on astmevahelduseta, astmevahelduse liigilt vältevahelduslik, lõpuvahelduseta, nimetav lõpeb vokaaliga või omastavatüves on kolm silpi. Lõpuvaheldusmallide järgi on illatiivi kasutamine tõenäolisem $(\mathrm{V}) s$-lõpuliste sõnade puhul, aga ka suur-ning küünal-tüüpi sõnade puhul, samuti(V)ne- ja ke-lõpuliste sõnade ning soolane-, uus-küüs- ja käsi-tüüpi sõnade puhul. Seejuures tuleb rõhutada, et siinses materjalis leidus esinemiskordade järgi kõigi tunnuste puhul rohkem aditiivivorme. Siiski on tulevaste uurimuste tarvis kasulik, et selgusid tunnused, mille korral ka illatiivi kasutamine on statistiliselt tõenäoline. Neid tunnuseid saab kasutada mitmetunnuselises analüüsis, kus selgitada statistiliste meetoditega sisseütleva vormi valikut üksikasjalikumalt. Hii-ruut-testi järgi ei ole sisseütleva valikul statistiliselt olulised tunnused astmevaheldusmall (tugevnev või nõrgenev astmevaheldus) ega algvormi välde.

Juba artiklis toodud näidete põhjal on näha, et tunnuste vahel on tugev omavaheline seos. Näiteks kõik konsonandiga lõppevad sõnad on lõpuvahelduslikud (lisandub tüvevokaal), nii et on ootuspärane, et nende tunnustega sõnade puhul eelistatakse sama vormi (näidetena toodud aeda, aega, akti jne). Samadele omadustele vastavad sõnad kuuluvad samadesse muuttüüpidesse ja siit oleks võimalik üldistada muuttüüpide sisseütleva valikut. 
Artiklis esitati aditiivi või illatiivi tõenäolisem kasutamine vaid ühe tunnuse järgi. Leiti, millised tunnused on statistiliselt olulised, st milliseid tunnuseid saaks kasutada tulevikus mitmetunnuselises analüüsis. Ka tuleks edaspidi uurida morfosüntaktilisi ja semantilisi tunnuseid, et kirjeldada eesti keele sisseütleva valikuid veelgi täpsemalt.

\section{Kirjandus}

Agresti, Alan 2013. Categorical Data Analysis. 3rd Ed. Wiley Series in Probability and Statistics. New Jersey, Hoboken: John Wiley \& Sons Inc.

Alvre, Paul 1995. Soome väljendid eesti vastetega. Tallinn: Valgus.

Arppe, Antti 2008. Univariate, Bivariate, and Multivariate Methods in Corpusbased Lexicography - a Study of Synonymy. University of Helsinki. Helsinki: Helsinki University Print.

EKG = Mati Erelt, Reet Kasik, Helle Metslang, Henno Rajandi, Kristiina Ross, Henn Saari, Kaja Tael, Silvi Vare 1995. Eesti keele grammatika. I. Peatoim. Mati Erelt, toim. Tiiu Erelt, Henn Saari, Ülle Viks. Tallinn: Eesti Teaduste Akadeemia Eesti Keele Instituut.

EKK = Mati Erelt, Tiiu Erelt, Kristiina Ross 2007. Eesti keele käsiraamat. Kolmas, täiendatud trükk. Tallinn: Eesti Keele Sihtasutus.

Hasselblatt, Cornelius 2000. Eesti keele ainsuse sisseütlev on lühike. - Keel ja Kirjandus 11, 796-803.

Kaalep, Heiki-Jaan 2009. Kuidas kirjeldada ainsuse lühikest sisseütlevat kasutamisandmetega kooskõlas? - Keel ja Kirjandus 6, 411-425.

Kaalep, Heiki-Jaan 2012. Eesti käänamissüsteemi seaduspärasused. - Keel ja Kirjandus 6, 418-449.

Kio, Kati 2006. Sisseütleva käände kasutus eesti kirjakeeles. Magistritöö. Käsikiri Tartu Ülikooli eesti keele osakonnas.

Klavan, Jane 2012. Evidence in Linguistics: Corpus-linguistic and Experimental Methods for Studying Grammatical Synonymy. (= Dissertationes linguisticae Universitatis Tartuensis 15.) Tartu: University of Tartu Press.

Laugaste, Gerda 1964. Mida andis ülevabariigiline emakeele olümpiaad. - Keel ja Kirjandus 7, 392-398; 8, 467-476.

Nurm, Ernst 1939. 1937. a. gümnaasiumi vastuvõtu-eksami tööde ortograafiline külg. - Eesti Keel 1, 10-14.

Raag, Virve 1998. The Effects of Planned Change on Estonian Morphology. (= Studia Uralica Upsaliensia 29.) Uppsala: Universitet Uppsala.

Rajandi, Henno 1963. Morfeemide liigitus deskriptiivses lingvistikas. - Keel ja Kirjandus 7, 409-414. 
R Development CoreTeam 2013. R: A Language and Environment for Statistical Computing. R Foundation for Statistical Computing. http://www.rproject.org/ (10.04.2015).

Sõnajalg, Ingrid 1956. Illatiiv eesti kirjakeeles. Diplomitöö. Käsikiri Tartu Ülikooli eesti ja üldkeeleteaduse instituudis.

Viitso, Tiit-Rein 1976. Eesti muutkondade süsteemist. - Keel ja Kirjandus 3, $148-162$.

Viks, Ülle 1992. Väike vormisõnastik. I, Sissejuhatus ja grammatika. Tallinn: Eesti Teaduste Akadeemia, Keele ja Kirjanduse Instituut.

VÕS 1940 = Väike õigekeelsus-sõnaraamat. Koost. Elmar Muuk. Seitsmes trükk. Tartu: Eesti Kirjanduse Selts.

VÕS 1953 = Väike õigekeelsuse sõnaraamat. Eesti NSV Teaduste Akadeemia Keele ja Kirjanduse Instituut. Tallinn: Eesti Riiklik Kirjastus.

ÕS 1960 = Õigekeelsuse sõnaraamat. Toim. Ernst Nurm, Erich Raiet, Magnus

Kindlam. Eesti NSV Teaduste Akadeemia Keele ja Kirjanduse Instituut.

Tallinn: Eesti Riiklik Kirjastus.

ÕS 1976 = Õigekeelsussõnaraamat. Toim. Rein Kull, Erich Raiet. Eesti NSV

Teaduste Akadeemia Keele ja Kirjanduse Instituut Tallinn: Valgus.

ÕS 2013 = Eesti õigekeelsussõnaraamat ÕS 2013. Toim. Maire Raadik. Koost.

Tiiu Erelt, Tiina Leemets, Sirje Mäearu, Maire Raadik. Eesti Keele Instituut. Tallinn: Eesti Keele Sihtasutus.

\section{Korpused}

Morfoloogiliselt ühestatud korpus. http://www.cl.ut.ee/korpused/morfkorpus/ (27.01.2015).

Ann Metslang

eesti ja üldkeeleteaduse instituut

Tartu Ülikool

Jakobi 2

51014 Tartu

ann.metslang@ut.ee 


\title{
How the choice between the singular long and short illative case depends on the type of morphophonological variables - a corpus analysis
}

\author{
ANN METSLANG
}

This study examines the choice between the singular long and short illative case. The research question examined is which morphophonological variables are statistically significant for choosing the long or short illative case. The variables considered were gradation, the type and direction of gradation, the quantity degree of the base form, stem-final alternation and the stem-final alternation pattern, the final sound of the base form and the number of syllables in the genitive stem. The data for the study came from the Morphologically Disambiguated Corpus of the University of Tartu. A total of 1710 illative case forms were analysed. With the help of the computer software program $\mathrm{R}$, a chi-square test and standardized Pearson residuals were performed.

Based on the standardized Pearson residuals, the short illative is more likely when the word has gradation or quality alternation, the word has stem-end alternation, the final sound of the word's base form is a consonant or there are more than three syllables in the genitive stem. Likewise, the short illative is more likely when the stem-final alternation pattern has words belonging to the seminar, redel, kringel, siil, sai, lagi, nali, sõber and õnnelik types. The long illative is more likely if the word has no gradation (or has quantity alternation), the word has no stem-final alternation (or the stem-final alternation pattern has the ending -(V)s, if the word has the ending -(V)ne or -ke, if the word belongs to the suur, küunal, soolane, uus-küüs, or käsi type, the final sound of the word's base form is a vowel or there are three syllables in the genitive stem. The direction of gradation and the quantity degree of the base form are not statistically significant factors in the choice between the short and the long illative. However, the short illative form was preferred by all morphophonological variables in the analysed data.

Future studies could perform a multivariate analysis with morphosyntactic and semantic variables.

Keywords: morphology, morphophonology, corpus linguistics, language variation, illative, short illative, Estonian 